\title{
GIBSON PARADOX REVISITED - LIQUIDITY CHAIN EFFECT
}

\author{
Marinko ŠKARE ${ }^{1}$, Lorena MOŠNJA-ŠKARE ${ }^{2}$ \\ Faculty of Economics and Tourism, Juraj Dobrila University of Pula, \\ Preradoviceva 1/1, 52100 Pula, Croatia \\ E-mails: ${ }^{1}$ mskare@unipu.hr (corresponding author); ${ }^{2}$ lmosnja@unipu.hr
}

Received 07 October 2014; accepted 03 November 2014

\begin{abstract}
Gibson paradox remains a puzzle in the discipline of economics. Previous studies attempted to resolve the paradox looking separately at the gold standard, changing monetary regimes, inflation expectations, risk and uncertainty. Our study shows Gibson paradox holds for the Netherlands 1800-2012 with real long interest rates and prices diverging after 2008. This paper offers empirical evidence (nonlinear cointegration) on the integrity of the Gibson paradox. Single factor cannot explain the paradox itself (because of its nonlinear nature) as previous studies attempted. Empirical link between long interest rates and prices is caused by complex interaction between purchasing power, liquidity, gold prices, market turnover, stocks accumulation, productivity, short-term interest rates. This approach analysis the purchasing power and price relation, resulting in firms' turnover and liquidity shifts, leading to short-term borrowings changes and pressures on interest rates in the short as well as in long-term. Actually, the model enables us to track the series of price change effects finally resulting in interest rates shifts, via a set of microeconomic and financial laws, which taken at the aggregate level could offer the Gibson paradox explanation. Further studies must explore nonlinear nature of the paradox in order to explain it. Study results have important implications for policy makers and firm governance policy.
\end{abstract}

Keywords: Gibson paradox, purchasing power, prices, liquidity chain effect, capital markets, the Netherlands.

JEL Classification: B2, C5, E43, E52, G1.

\section{Introduction}

Gibson (1923) tried to explain the interest rates and prices relationship by looking at the "sympathetic" movement between the course of commodity prices and the course of the yield on British Consols 1820-1922 (long term interest rate or LR later in the text). The price of stock (first-class securities) following his economic reasoning is determined indirectly through the cost of living. A rise in the cost of living is followed by a rise in the yield of high-class fixed interest-bearing stocks - Gibson Law. Keynes (1930) was puzzled by the relationship between long-term interest rates and level of wholesale prices Gibson uncovered. Strongly believing in long-term interest rates and general price level change (inflation) link, Keynes forged the term Gibson paradox. Fase 
(1972) presents evidence on the Gibson paradox existence for the Netherlands for the period 1901-1971. He finds Gibsons' paradox to hold under observed time. Van den End (2011) finds a weak statistical evidence for mean reversion of long-term interest rates for the Netherland 1800-2010. Wicksell (1936) uses two rate differential theory (money and natural interest rate) to explain the long run dynamics between prices and interest rates. Banks overshooting/underbidding of natural interest rates impact prices, which in turn over expected inflation influence nominal interest rate in the long run. Harrod-Keynes effect in Clayton et al. (1971) looked at the real interest rate and prices relationship assuming no relation between prices and nominal rates. Barsky and Summers (1988) offer a different perspective from the gold standard mechanism point of view with reciprocal dynamics between the gold price and price level accounting for changes in real interest rate. Dynamic relationship between real interest rates and prices can be explained by the negative equilibrium relationship between relative price of gold and real interest rates. Shiller and Siegel (1977) explain historical movement in real interest rates and prices as a consequence of unanticipated price change on wealth redistribution mechanism affecting nominal denominated assets interest rate. Sargent (1973) using spectral analysis technique finds interest and prices to be mutually dependent thus disproving Fisher (1930) theory of the paradox. In recent article, Cogley et al. (2011) detect inflation targeting/anchoring, i.e. changes in the monetary policy behind the reappearance of the Gibson paradox after 1995 in USA.

Research results from previous studies clearly addressed the Gibson paradox from the standpoint of trying to identify a one principal explanatory factor behind the phenomenon, ignoring possible nonlinear behaviour in interest rates or prices. Consequently, such a complex phenomenon cannot be explained on such research ground.

Offering an alternative research background, the purpose of this paper is to answer several important questions (research objectives):

1) Gibson paradox is a true historical economic fact or statistical foe?

2) Does it hold just for Britain over a long time series period?

3) What complex mechanism lies behind this phenomenon?

4) Can unraveling the true nature of paradox help developing a more advanced modern interest rate theory?

Since no valid and explicit theory has been offered able to fully explain this "established empirical fact" Gibson paradox still remains a puzzle for more than two centuries.

Introduction gives main points on the Gibson paradox with section 1 offering a review on the phenomena. Section 2 lists data sources and variables used in this paper. Section 3 introduces liquidity-chain effect theory and model with discussion on the developed model in the section 4 .

\section{On the Gibson paradox}

Gibson (1923), Keynes (1976), Fisher (1997), Wicksell (1936), Mises and Greaves (2011) failed to explain the Gibson paradox fully. Failure to do so was a consequence of the narrow view on the paradox. In an attempt to explain the paradox, they were both 
wrong and right in the same time. Gibson paradox has something to do with costs of living as suggested by Gibson (1923), but cannot be explained by price index dynamics. Natural interest rate as defined by Keynes (1976) natural interest rate effect strongly influences dynamics of the long-term interest rates on Dutch bonds but cannot explain the paradox alone. Price premium (Fisher effect), as defined by Fisher (1997), is also an important part in explaining the nature of the Gibson paradox. Keynes (1976) attacks on Fishers' view (nominal interest rate influenced by changes in expected inflation) claiming that long-term interest rates and price level move in the opposite direction proved to be wrong. In fact, correlation between long-term interest rates and price level in the Netherlands over 1800-2012 is 0.3357 . Expected inflation has no significant direct impact on long-term interest rate, but it is an important part of the Gibson paradox model. Price premium strongly influences uncertainty conditions (bidirectional causality) in the economy and thus indirectly affecting the long-term relationship between bonds interest rates and cost of living. Fields (1984) and Fase (1972) provide a quantitative analysis of the Gibson paradox in the Netherlands over 1901-1974 and 1901-1971. Using standard OLS, Fase (1972) finds a positive correlation between LR and CPI caused by a third variable and trend in real interest rate. Fields (1984) used ARIMA and Three stage OLS to correct for spurious regression since he finds CPI to be I(1) and LR following random walk. He also provides evidence for the Gibson paradox presence in the Netherlands as "integral part of a wider set of economic relationships". Gibson paradox is caused by nominal government purchases shocks through the IS-LM scheme. Rising government purchase shifts IS curve to the right causing interest rates, real income and the price level to rise too. Shiller and Siegel (1977) use spectral analysis on time series data (long term interest rate on British Consols) and log of the price index test, Fisher's inflationary expectation theory and Keynes (1930), Wicksell (1936) interest sensitive money supply, Sargent (1973) interest-elastic demand for money. They find no evidence to support both inflationary expectation and interest sensitive money supply/demand theories as plausible explanations for Gibson phenomenon. Shiller and Siegel (1977) offer an alternative view on the Gibson paradox with unanticipated changes in price level redistributing wealth from creditors to debtors affecting interest rates for nominally denominated assets. A multicountry perspective on the Gibson paradox and Fisher's effect after the WW II period in terms of Granger-causality can be found in Ram (1987). His research also finds limited support for the Fisher's effect as possible explanation for the Gibson paradox. Gootzeit (1991) offers a detailed review on the Gibson paradox from the Wicksell's theory point of view and Fisher's equation mechanism.

A recent paper on the Gibson paradox by Cogley et al. (2011) shows evidence of the Gibson paradox reappearance after 1995. Changes in monetary policy, particularly price indexation and anti-inflationary measures, contributed to the reappearance of the Gibson paradox after the 70's Great inflation era. To improve the understanding of the relationship between nominal interest rate and price level, Muscatelli and Spinelli (1996) compare the Gibson phenomenon dynamics in Italy, England and USA. Research results from the study give supportive evidence to the theory advanced by Barsky and Summers (1988) that the gold standard can serve as the principal explanation factor behind the paradox. 
Implication of the paradox on the capital markets in transitional countries has been considered in Minović (2012) and the relationship between money supply and interest rates in Bozoklu (2013). Emerging economies also show a possible sign of Gibson paradox effect as shown in Afzal and Mirza (2012). The link between risk and government bonds interest rates for transitional countries is studied in Ivanovski et al. (2013).

\section{Data sources and time series properties}

Main data sources used in the paper are Smits et al. (2000), Zanden and Riel (2000), Hart et al. (2010), Zanden and Lindblad (1989), Bos (2008), Homer and Sylla (2011), Jacobs and Smits (2001), van den End (2011), Barro and Ursúa (2008), Officer and Williamson (2013), Reinhart and Rogoff (2009), Statistics Netherland (2010, 2011), Jan-Pieter et al. (2000), van Bochove and Huitker (1987), Centraal Bureau voor de Statistiek and Rijksuniversiteit Groningen (2001), De Nederlandsche Bank (2013), International Institute of Social History (2013), Jacobs and Smits (2001), CBS Historical Series (2014).

Time series in levels and first difference for interest (LR), prices (CPI) and (LogCPI) over the entire sample appear to be nonlinear (possible heteroskedasticity issue also) with series descriptive statistics in the Table 1.

Table 1. Time series descriptive statistics

\begin{tabular}{lcccccc}
\hline \multirow{2}{*}{$\begin{array}{c}\text { Sample } \\
\text { 1800-2012 }\end{array}$} & \multicolumn{3}{c}{ Level } & \multicolumn{3}{c}{ First difference } \\
\cline { 2 - 7 } Mean & LR & CPI & LogCPI & LR & CPI & LogCPI \\
\hline Median & 4.778 & 258.153 & 4.880 & -0.0227 & 6.22261 & 0.0128 \\
\hline Maximum & 11.59 & 1413.76 & 7.25401 & 1.9 & 47.6613 & 0.1749 \\
\hline Minimum & 1.93225 & 48.1753 & 3.87485 & -1.75 & -15.7623 & -0.1942 \\
\hline Std. stat. dev. & 1.644 & 359.400 & 1.036 & 0.501 & 12.2615 & 0.0529 \\
\hline Skewness & 1.339 & 1.865 & 1.146 & 0.394 & 1.458 & -0.3869 \\
\hline Kurtosis & 4.812 & 5.099 & 2.808 & 5.871 & 4.867 & 4.614 \\
\hline Jarque-Bera & 92.777 & 162.505 & 46.954 & 78.133 & 105.492 & 28.3034 \\
\hline Probability & 0.00 & 0.00 & 0.00 & 0.00 & 0.00 & 0.00 \\
\hline Observations & 213 & 213 & 213 & 213 & 213 & 213 \\
\hline
\end{tabular}

Source: authors' calculation.

Statistics from the Table 1 exceeds the critical values for any reasonable significance level proving interest and price series in the Netherland over the sample period do not follow a normal distribution. Reported statistics shows clear evidence of excess in skewness and kurtosis for all series. All this is evidence of possible nonlinearities in the data. To check for the nonlinearity in the series, the method developed by Kočenda (2001) is 
used to test the iid hypothesis by slope of the log correlation integral calculation (see test results in the Table 2).

$$
\beta_{m}=\frac{\sum_{\varepsilon}\left(\ln (\varepsilon)=\overline{\ln (\varepsilon)} \times\left(\ln \left(C_{m}(\varepsilon)\right)-\overline{\ln \left(C_{m}(\varepsilon)\right)}\right)\right.}{\sum_{\varepsilon}(\ln (\varepsilon)-\overline{\ln (\varepsilon)})^{2}} .
$$

Test results from the Table 2 confirm interest and price series in the Netherland show nonlinear dynamic behaviour. Estimated $\beta_{(m)}$ values reject the null of iid at $1 \%$ level for all series (LR, CPI, LogCPI) verifying nonlinear dependence in the data.

Table 2. Power test of slope coefficient $\beta_{\mathrm{m}}$ (null of iid rejected at $1 \%$ level)

\begin{tabular}{lccccccccc}
\hline \multicolumn{1}{c}{ Series } & $\beta_{2}$ & $\beta_{3}$ & $\beta_{4}$ & $\beta_{5}$ & $\beta_{6}$ & $\beta_{7}$ & $\beta_{8}$ & $\beta_{9}$ & $\beta 10$ \\
\hline LR & 0.73 & 0.837 & 0.936 & 1.03 & 1.116 & 1.202 & 1.287 & 1.371 & 1.454 \\
\hline CPI & 0.16 & 0.161 & 0.162 & 0164 & 0.165 & 0.166 & 0.167 & 0.169 & 0.17 \\
\hline LogCPI & 0.371 & 0.382 & 0.392 & 0.403 & 0.414 & 0.424 & 0.435 & 0.446 & 0.458 \\
\hline
\end{tabular}

Source: authors' calculation.

Nonlinear dependence in the series is also checked using standard BDS test (Broock et al. 1996) and test results are presented in the Table 3. BDS test results uphold the Power test results validating nonlinear patterns detected in the series.

Table 3. BDS test results for LR, CPI, $\log C P I$

\begin{tabular}{cccccc}
\hline Dimension & BDS statistic & Std. error & z-Statistic & Normal prob. & Bootstrap prob. \\
\hline 2 & 0.198160 & 0.009131 & 21.70133 & 0.0000 & 0.0000 \\
\hline 3 & 0.333570 & 0.014641 & 22.78336 & 0.0000 & 0.0000 \\
\hline 4 & 0.427322 & 0.017604 & 24.27444 & 0.0000 & 0.0000 \\
\hline 5 & 0.492849 & 0.018534 & 26.59235 & 0.0000 & 0.0000 \\
\hline 6 & 0.539157 & 0.018059 & 29.85527 & 0.0000 & 0.0000 \\
\hline \hline Raw epsilon & 419.2068 & & \\
\hline Pairs within epsilon & 32031.00 & V-Statistic & 0.706011 & \\
\hline Triples within epsilon & 5459233 & V-Statistic & 0.564928 \\
\hline
\end{tabular}

Source: authors' calculation.

Empirical assessment presented here so far provides sufficient evidence that Gibson paradox does exist in the Netherlands. However, results were challenged by the loss in correlation coefficient (over the whole sample) after prewhitening the series. That could raise some question on whether positive nonspurious correlation between LR and CPI, LogCPI for the Netherlands truly holds, i.e. does the Gibson Paradox even exists in the Netherland. To discard the possibility of spurious relationship between interest rates and 
prices, rolling correlations coefficients between LR and CPI, LogCPI on prewhitened series are calculated confirming the presence of Gibson Paradox in the Netherlands (although not so frequent as correlation on raw series suggests). This result suggests that Gibson Paradox for the Netherlands is not a consequence of spurious correlation between interest rates (LR) and prices (CPI, LogCPI). The distinct difference however appears. Correlation coefficients on raw data show Gibson Paradox in the Netherland appears more regularly and poorly holds after 1952/1976. Rolling correlation on the prewhitened data shows Gibson Paradox is evenly existent over the sample period and does not disappear after 1976. Since the overall results uphold Gibson Paradox does occur in the Netherland, nonlinearity, nonstationarity and no cointegration issues that could invalidate the results have to be addressed.

First the stationarity behavior of the series is considered using a battery of standard unit root tests. Unit root test used includes Augmented Dickey-Fuller (ADF) (Dickey and Fuller 1979), Phillips-Perron (PP) (Phillips, Perron 1988), Ng-Perron (NP) (Ng et al. 2001), Dickey-Fuller test with GLS Detrending (DFGLS) (Elliott et al. 1996), Kwiatkowski, Phillips, Schmidt and Shin (KPSS) test (Kwiatkowski et al. 1992), Elliot, Rothenberg and Stock Point Optimal (ERS) test (Elliott et al. 1996). A relatively large number of the unit root tests is used in order to deal with the problems of nonstationarity as suggested in Maddala and Kim (1998). Test results of the unit root analysis are reported in Table 4.

Table 4. Stationarity test results for the series LR, CPI, LogCPI

\begin{tabular}{|c|c|c|c|c|c|c|c|}
\hline Test & & $\mathrm{ADF}$ & Phillips-Perron & ADFGLS & ERS & KPSS & NP \\
\hline $\operatorname{Null}\left(\mathrm{H}_{0}\right)$ & & Unit root & Unit root & Unit root & Unit root & Stationarity & Unit root \\
\hline LR & & -2.383 & -2.205 & -1.404 & 5.517 & 0.279 & -5.800 \\
\hline CPI & & 3.939 & 6.479 & 3.627 & 175.3 & 1.138 & 5.348 \\
\hline LogCPI & & 1.574 & 1.980 & 1.803 & 70.43 & 1.321 & 2.306 \\
\hline \multicolumn{8}{|l|}{ Critical values } \\
\hline & $1 \%$ & -3.461 & -3.461 & -2.575 & 1.915 & 0.739 & -13.80 \\
\hline & $5 \%$ & -2.875 & -2.874 & -1.942 & 3.178 & 0.463 & -8.100 \\
\hline & $10 \%$ & -2.574 & -2.574 & -1.615 & 4.339 & 0.347 & -5.700 \\
\hline
\end{tabular}

Test results in the Table 4 show price series are not stationary at conventional significance level of $1 \%$ and $5 \%$. In fact, CPI series is integrated of order I(1), except for KPSS, showing second order of integration. Long-term interest rate series LR appear to be also integrated I(1) although not all unit root test agrees (ADFGLS - second order of integration, KPSS - stationary in levels and NP - higher order of integration). Logarithm of the CPI series for most of the unit root tests show to be I(1) except for KPSS I(2). Since the majority of the unit root test results characterize long-term interest rates on Dutch bonds and prices as I(1), series Johansen (1988) and Johansen-Juselius 
(1990) cointegration tests are used. Test results are presented in Table 5. To account for possible structural break in the data Gregory and Hansen (1996) cointegration test is applied and test results are presented in Table 5.

Table 5. Cointegration test results for the series LR, CPI, LogCPI

\begin{tabular}{|c|c|c|c|}
\hline \multicolumn{4}{|c|}{ Cointegration tests } \\
\hline \multirow[t]{2}{*}{ Null hypothesis (LR and CPI) } & \multicolumn{3}{|c|}{ Johansen (1988) } \\
\hline & $\mathrm{J}_{\text {trace }}$ & \multicolumn{2}{|c|}{$\mathrm{J}_{\max }$} \\
\hline$r=0$ & $\begin{array}{c}24.567 \\
(0.0017)\end{array}$ & \multicolumn{2}{|c|}{$\begin{array}{c}24.515 \\
(0.0000)\end{array}$} \\
\hline $\mathrm{r}=1$ & $\begin{array}{c}0.0517 \\
(0.8200)\end{array}$ & \multicolumn{2}{|c|}{$\begin{array}{c}0.0517 \\
(0.8200)\end{array}$} \\
\hline Null hypothesis (LR and CPI) & \multicolumn{3}{|c|}{ Johansen - Juselius (1990) } \\
\hline & $\mathrm{J}_{\text {trace }}$ & \multicolumn{2}{|c|}{$\mathrm{J}_{\max }$} \\
\hline $\mathrm{r}=0$ & 29.192 & \multicolumn{2}{|c|}{29.018} \\
\hline $\mathrm{r}=1$ & 0.1744 & \multicolumn{2}{|c|}{0.1744} \\
\hline \multirow[t]{2}{*}{ Null hypothesis (LR and CPI) } & \multicolumn{3}{|c|}{ Gregory - Hansen (1996) } \\
\hline & $1 \%$ & $5 \%$ & $10 \%$ \\
\hline$Z_{t}=-4.66$ & -5.13 & -4.61 & -4.34 \\
\hline $\mathrm{Z}_{\mathrm{a}}=-36.26$ & -50.07 & \multicolumn{2}{|c|}{$-40.48-36.19$} \\
\hline $\mathrm{ADF}=-4.50$ & -5.13 & -4.61 & -4.34 \\
\hline Null hypothesis (LR and LogCPI) & \multicolumn{3}{|c|}{ Johansen (1988) } \\
\hline & $\mathrm{J}_{\text {trace }}$ & \multicolumn{2}{|c|}{$\mathrm{J}_{\max }$} \\
\hline $\mathrm{r}=0$ & $\begin{array}{c}9.8962 \\
(0.2888)\end{array}$ & \multicolumn{2}{|c|}{$\begin{array}{c}9.2463 \\
(0.2662) \\
\end{array}$} \\
\hline $\mathrm{r}=1$ & $\begin{array}{c}0.6498 \\
(0.4202)\end{array}$ & \multicolumn{2}{|c|}{$\begin{array}{c}0.6498 \\
(0.4202)\end{array}$} \\
\hline \multirow[t]{2}{*}{ Null hypothesis (LR and LogCPI) } & \multicolumn{3}{|c|}{ Johansen - Juselius (1990) } \\
\hline & $\mathrm{J}_{\text {trace }}$ & \multicolumn{2}{|c|}{$\mathrm{J}_{\max }$} \\
\hline$r=0$ & 11.132 & \multicolumn{2}{|c|}{9.746} \\
\hline $\mathrm{r}=1$ & 1.383 & \multicolumn{2}{|c|}{1.384} \\
\hline \multirow[t]{2}{*}{ Null hypothesis (LR and $\log C P I)$} & \multicolumn{3}{|c|}{ Gregory - Hansen (1996) } \\
\hline & $1 \%$ & $5 \%$ & $10 \%$ \\
\hline$Z_{t}=-2.98$ & -5.13 & -4.61 & -4.34 \\
\hline$Z_{a}=-17.36$ & -50.07 & -40.48 & -36.19 \\
\hline $\mathrm{ADF}=-2.78$ & -5.13 & -4.61 & -4.34 \\
\hline
\end{tabular}


Cointegration test results (with and without possible break in the data) confirm LR and CPI are cointegrated with one cointegration equation at standard statistical levels. Cointegration test results for LR and LogCPI follow the results from Corbae and Ouliaris (1989) finding nominal interest rates and the price level for UK/US 1920-1987 integrated but not forming a cointegrated system. Further they asses that positive correlation between interest rates and prices for integrated variable but lacking of cointegration could be misleading showing the presence of Gibson Paradox when there is not any. Our results for the Netherlands prove the existence of cointegrating relation between nominal interest rates LR and price level CPI. Following Corbae and Ouliaris (1989) positive correlation resulting from a properly specified cointegrated model we find between LR and CPI for the Netherlands prove the existence of an economic relationship in the data, i.e. Gibson Paradox existence. Additional evidence supporting the existence of Gibson paradox for the Netherlands is found using likelihood-ratio and Wald test (cointegrating vector restrictions). Both test results indicate one cointegrating relationship in the system. The same solid statistical evidence for LR and LogCPI economic relation for the Netherlands is not found and thus established positive correlation between LR and LogCPI could be misleading (possibly because of nonlinearity in the data). To check the results of the cointegration test linear Granger causality tests are performed and results are presented in the Table 6.

Table 6. Linear granger causality test (prewhitened series)

\begin{tabular}{lccc}
\hline \multicolumn{4}{c}{ Linear granger causality test } \\
\hline Null hypothesis (Lags 1 - 4) & Obs. & F-stat. & Prob. \\
\hline LR does not granger cause CPI & 205 & 4.211 & 0.0027 \\
\hline CPI does not granger cause LR & & 0.875 & 0.4794 \\
\hline Null hypothesis (Lags 5 - 15) & Obs. & F-stat. & Prob. \\
\hline LR does not granger cause CPI & 194 & 1.774 & 0.0422 \\
\hline CPI does not granger cause LR & & 1.706 & 0.0541 \\
\hline Null hypothesis (Lags 1 - 4) & Obs. & F-stat. & Prob. \\
\hline LR does not granger cause LogCPI & 205 & 0.664 & 0.6175 \\
\hline LogCPI does not granger cause LR & & 1.783 & 0.1337 \\
\hline Null hypothesis (Lags 5 - 15) & Obs. & F-stat. & Prob. \\
\hline LR does not granger cause LogCPI & 194 & 0.397 & 0.9783 \\
\hline LogCPI does not granger cause LR & & 0.742 & 0.7384 \\
\hline
\end{tabular}

Since misleading results (significant loss in correlation between nominal interest rates and price level) was previously found in the rolling correlation calculation for detrended and prewhitened series, Granger causality test was performed both on prewhitened LR and CPI, LogCPI series and first differenced series (see Table 7). 
Table 7. Linear granger causality test (first differences)

\begin{tabular}{lccc}
\hline \multicolumn{4}{c}{ Linear granger causality test } \\
\hline Null hypothesis (Lags $1-4)$ & Obs. & F-stat. & Prob. \\
\hline$\Delta$ LR does not granger cause $\Delta$ CPI & 208 & -2.774 & 0.028 \\
\hline$\Delta$ CPI does not granger cause $\Delta$ LR & & 0.691 & 0.599 \\
\hline Null hypothesis (Lags $5-15)$ & Obs. & F-stat. & Prob. \\
\hline$\Delta$ LR does not granger cause $\Delta$ CPI & 197 & 1.208 & 0.2703 \\
\hline$\Delta$ CPI does not granger cause $\Delta$ LR & & 1.786 & 0.0402 \\
\hline Null hypothesis (Lags $1-4)$ & Obs. & F-stat. & Prob. \\
\hline$\Delta$ LR does not granger cause $\Delta$ LogCPI & 208 & -0.3661 & 0.8320 \\
\hline$\Delta$ LogCPI does not granger cause $\Delta$ LR & & 1.257 & 0.2882 \\
\hline Null hypothesis (Lags $5-15)$ & Obs. & F-stat. & Prob. \\
\hline$\Delta$ LR does not granger cause $\Delta$ LogCPI & 197 & 0.4029 & 0.9768 \\
\hline$\Delta$ LogCPI does not granger cause $\Delta$ LR & & 0.6232 & 0.8531 \\
\hline
\end{tabular}

Unit root tests on the prewhitened series LR, CPI and LogCPI provide evidence that series are stationary in levels (test results not showed here). Since the results of the Granger causality test are known to be sensitive to lag order, lag intervals are used in the analysis. Test results from the Table 6 show there is evidence of bidirectional linear Granger causality between nominal long run interest rates and price level in the Netherlands over the observed period. Results hold for 5-15 lag interval length used in performing the test. Uni or bidirectional Granger causality is not found for LR and LogCPI series for all the common lag lengths. Unidirectional Granger causality running from LR to CPI (1-4 lags) is also found at 1\% statistical level. Evidence on bidirectional linear Granger causality support cointegration test results are previously presented. Also, if we take into account that rolling correlation is not removed after detrending the series, joining this fact with the linear Granger causality test results indicates long term correspondence between nominal interest rates and prices in the Netherlands (long memory). Nonetheless, the issue of proven nonlinearity in the series remains demanding a definite answer which of the modeling approach should be used in isolating the economic relationship between nominal interest rates and prices. Before choosing between linear and nonlinear modeling approach, nonlinear Granger causality test following (see Diks and Panchenko 2006) is executed (see Table 8 for results).

Table 8 reports evidence of bidirectional nonlinear Granger causality between nominal long-term interest rates (LR) and the price level (CPI) at $1 \%$ significance level. Standard test statistics from (see Diks and Panchenko 2006) is enough high offering substantial statistical evidence in favour of nonlinear causality in both direction (LR and CPI). Linear causality tests show bidirectional causality between LR and CPI only for prewhitened series. Nonlinear causality test suggests bidirectional nonlinear causality between 
Table 8. Nonlinear granger causality test

\begin{tabular}{lccc}
\hline \multicolumn{4}{c}{ Differenced series } \\
\hline Null Hypothesis & Obs. & T-stat. & Prob. \\
\hline LR does not granger cause CPI & 208 & 3.231 & 0.0006 \\
\hline CPI does not granger cause LR & & 2.719 & 0.0032 \\
\hline Null hypothesis & Obs. & T-stat. & Prob. \\
\hline LR does not granger cause LogCPI & 208 & -3.115 & 0.9990 \\
\hline LogCPI does not granger cause LR & & 0.302 & 0.3814 \\
\hline \multicolumn{1}{c}{ Prewhitened series } & & \\
\hline Null hypothesis & Obs. & T-stat. & Prob. \\
\hline LR does not granger cause CPI & 205 & 2.483 & 0.0065 \\
\hline CPI does not granger cause LR & & 2.453 & 0.0071 \\
\hline Null hypothesis & Obs. & T-stat. & Prob. \\
\hline LR does not granger cause LogCPI & 205 & -2.960 & 0.9985 \\
\hline LogCPI does not granger cause LR & & 0.394 & 0.3497 \\
\hline
\end{tabular}

Note: Bandwith $\varepsilon=1.5, l_{x}=l_{y}=4$.

LR and CPI is present both for differenced and prewhitened series. That is important since evidence of nonlinear causality between nominal long-term interest rates and price level have strong empirical and theoretical implication for the Gibson Paradox.

After finding evidence of bidirectional nonlinear causality between yields on Dutch Consols and price level, in order to find appropriate econometric specification, a nonlinear cointegration test is implemented. Following Diks and Panchenko (2006), (Choi et al. (2010), a NLLS estimation of the model:

$$
y_{t}=g\left(x_{t}, \theta\right)+\mu_{t}, \ldots, t=1,2, \ldots
$$

with residuals

$$
\tilde{u}_{t}=y_{t T}-g\left(x_{t T}, \tilde{\theta}_{T}\right)
$$

and $x_{t}\left(\begin{array}{lll}p & x & 1\end{array}\right)=I(1)$ regressor vector, $u_{t}=$ zero-mean stationary error term, $g\left(x_{t T}, \theta\right)$ smooth function of $x_{t}$ process and parameter vector $\theta(k x 1)$. Estimated residuals are checked with Kwiatkowski, Phillips, Schmidt and Shin (KPSS) test (Kwiatkowski et al. 1992) to determine if there exists nonlinear cointegration between LR and CPI (results non displayed here). To achieve robustness of the results, also another approach is used. First a long-run relationship between LR and CPI is estimated and stationarity of the residuals tested using mixing tests; KPSS and Lo (1991) (results non displayed here). KPSS test results from table above imply the existence of nonlinear cointegrating relationship between interest rates (LR) and prices (CPI) since the null of $u_{t}=I(0)$ is rejected in favor of $u_{t}=I(1)$ on residuals from NLLS. Results from both tests indicate 
the acceptance of mixing hypothesis, i.e. KPSS the rejection of I(0) in favour of I(1) and $\mathrm{R} / \mathrm{S}$ rejects the null of short-range dependence in favour of long-range dependence (long memory) at standard statistical levels and chosen lags (see Table 9).

Table 9. Nonparametric Lag Selection (NAR) for LR and CPI

\begin{tabular}{ccccc}
\hline Sample (1800-2012) & \multicolumn{2}{c}{ Long term interest rate (LR) } & \multicolumn{2}{c}{ Price level (CPI) } \\
\hline & AFPE & CAFPE & AFPE & CAFPE \\
\hline Constant & 0.13242021 & 0.13242021 & 24.050202 & 24.050202 \\
\hline Lag 1 & 0.25176569 & 0.25534082 & 45.958349 & 46.610969 \\
\hline Lag 2 & 0.22866937 & 0.24186665 & 33.487655 & 35.42034 \\
\hline Lag 3 & 0.19778411 & 0.22619756 & 27.749815 & 31.736323 \\
\hline Lag 4* & $0.17154472^{*}$ & $0.21958686^{*}$ & $31.768963^{*}$ & $40.666053^{*}$ \\
\hline Lag 5 & 0.17981005 & 0.26439277 & 58.143909 & 85.494828 \\
\hline Lag 6 & 0.18205572 & 0.31222351 & 96.61008 & 165.6852 \\
\hline Lag 7 & 0.22360408 & 0.44991851 & 184.87124 & 371.98334 \\
\hline Lag 8 & 0.35318789 & 0.83316339 & 433.47173 & 1022.5514 \\
\hline Lag 9 & 0.56545235 & 1.5562457 & 904.25104 & 2488.692 \\
\hline
\end{tabular}

\section{Liquidity chain effect - Gibson paradox revisited}

To explain the liquidity chain effect, empirical model is set up (chain liquidity model Gibson paradox curve) for the Netherlands following four periods under observation: $1800-1850,1850-1900,1900-1950,1950-2012$. The model is completely empirically derived although figures could associate readers with other theoretical textbook models, but this is not the case in this study. All curves in our models are derived from the data constructed over the period 1800-2012 for the Netherlands.

Figures 1-3 display the presence of the Gibson paradox during 1800-1950 sub periods. During 1800-1950 an increase in the price level (CPI) was followed by a fall in the purchasing power (purchasing power curve PPC) leading to low demand and stock building, consequently resulting in a drop in turnover ratio as a proxy for liquidity calculated on macro-economic level (Macro-liquidity curve MLC). Weak liquidity conditions on the market are in line with a reduction in net operating surplus (Operating surplus curve OSC). Low turnover and poor liquidity conditions present, push the demand for short term loans (Loanable funds curve LFC) to rise strongly to cover for insufficient working capital needed to sustain current production levels. Demand for short-term loans leads to the growth of short-term interest rates (Short term Gibson curve SGC) and, consequently, to an increase in interest rates for loans or bonds in the long term with high cost of living (Gibson curve GC).

Empirical curves in the Figures 1-4 are 3-year moving average curves derived from the real data used in study for the Netherlands. 

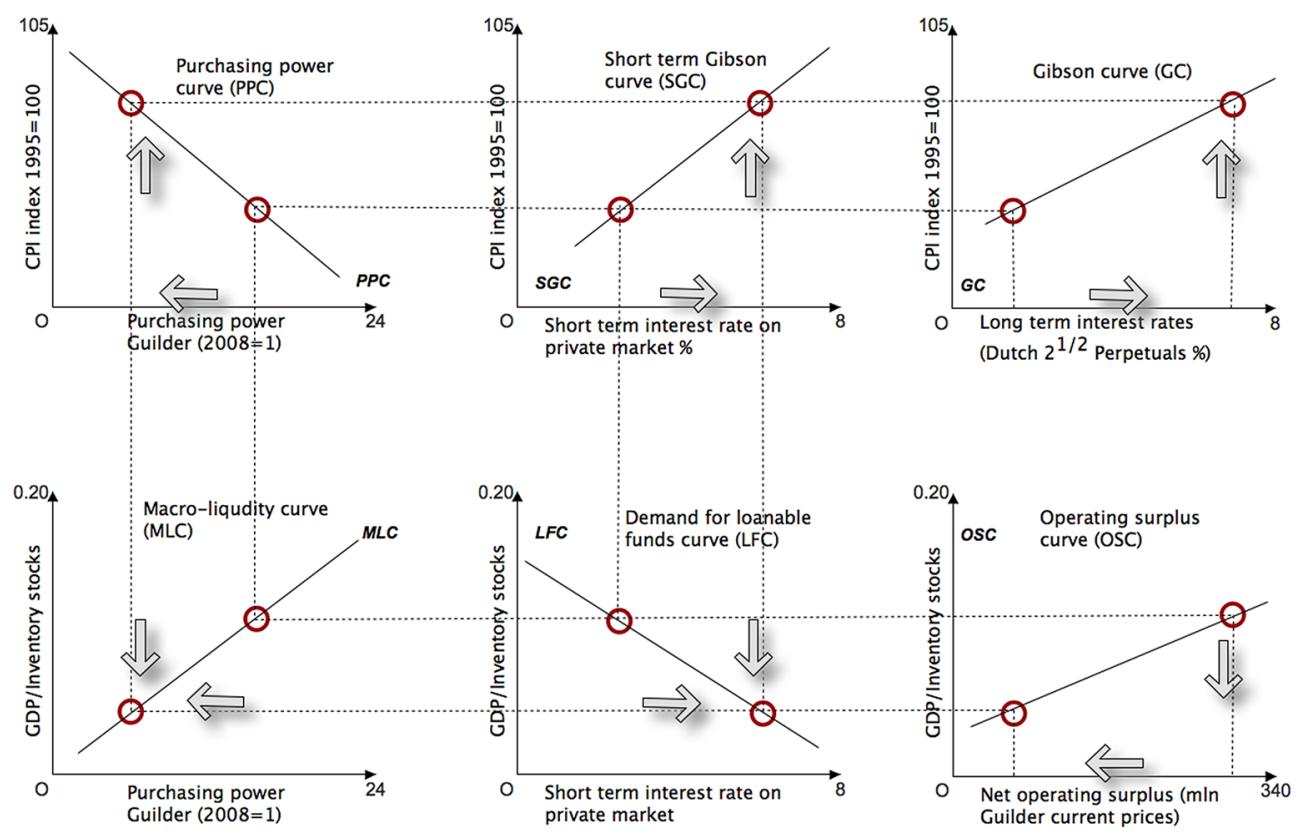

Fig. 1. Gibson paradox curve model (the Netherlands 1800-1850)

Source: authors' calculation.

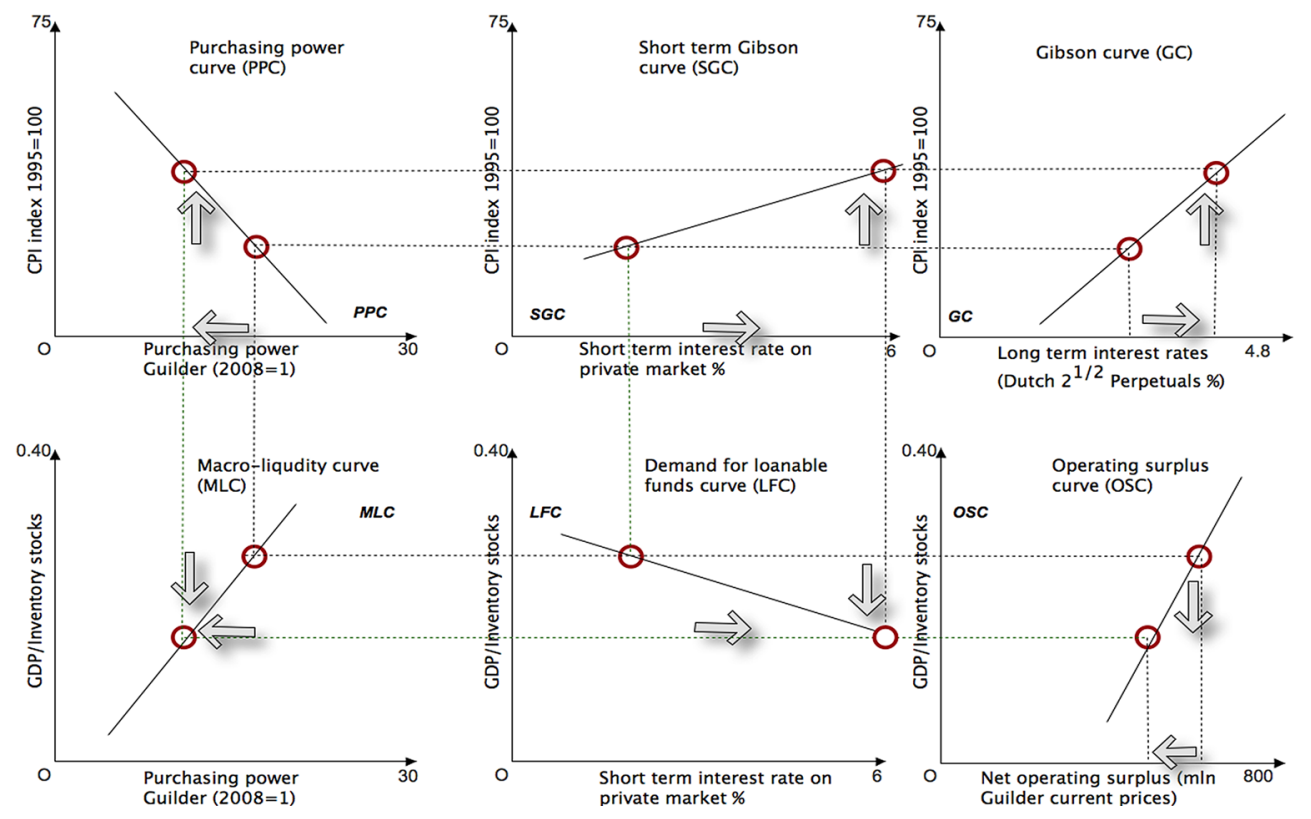

Fig. 2. Gibson paradox curve model (the Netherlands 1850-1900)

Source: authors' calculation. 


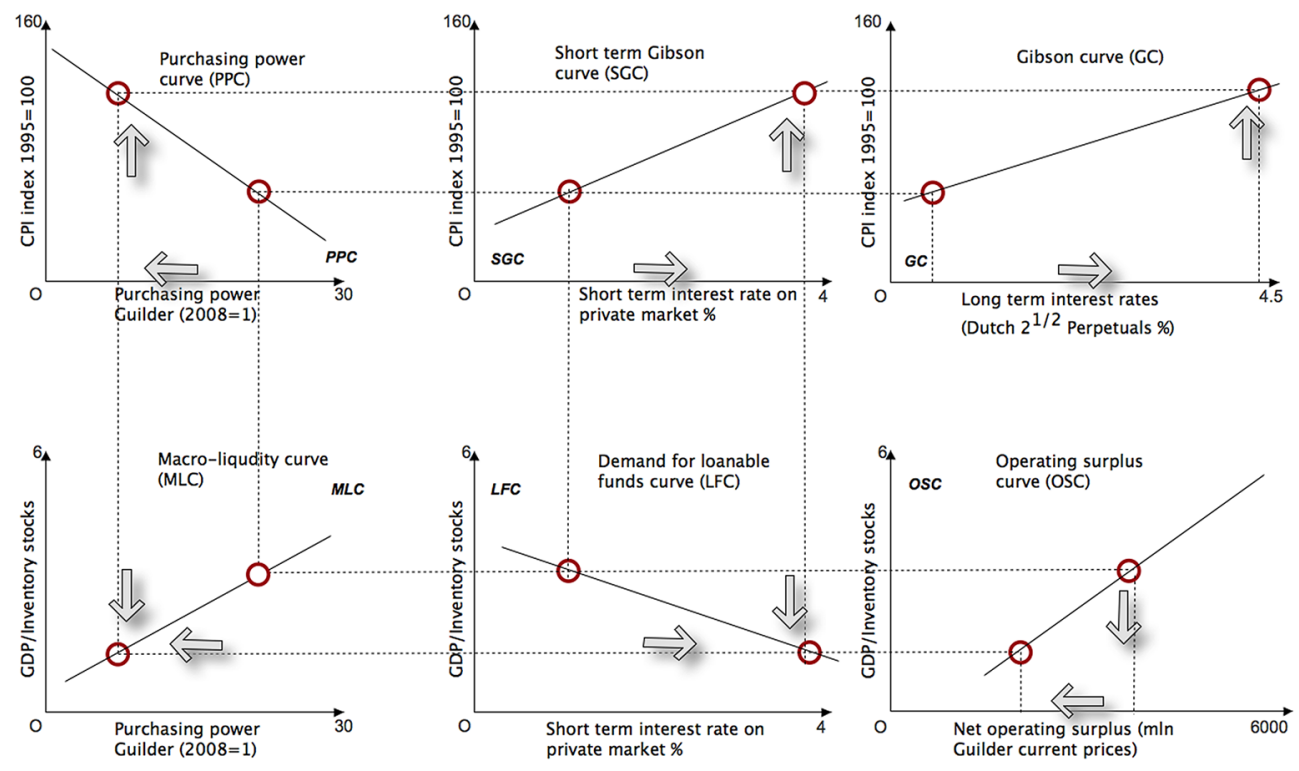

Fig. 3. Gibson paradox curve model (the Netherlands 1900-1950)

Source: authors' calculation.

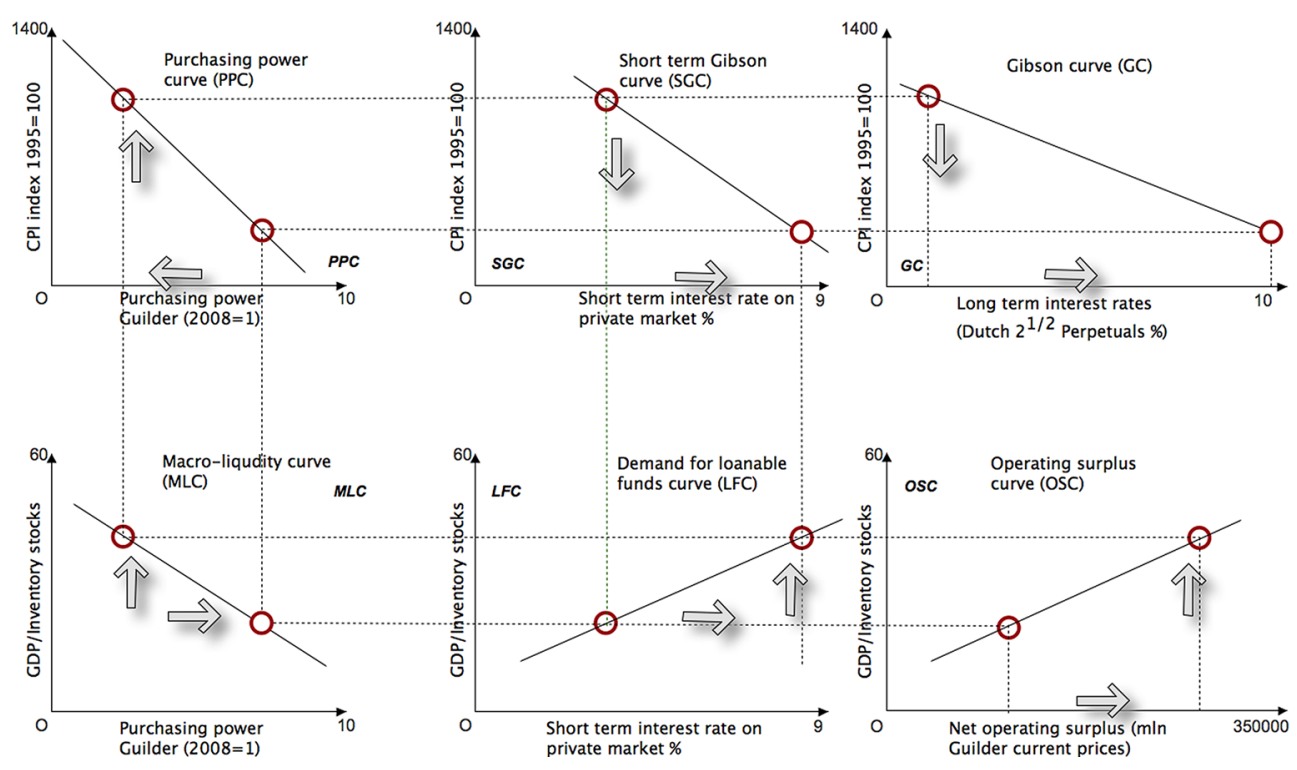

Fig. 4. Gibson paradox curve model (the Netherlands 1950-2012)

Source: authors' calculation. 
The impact on interest rates in the short and long term due to rising cost of living in the period 1800-1950 has changed depending on the elasticity of demands for loanable funds, liquidity preference curves and finally the Gibson curve. The reason for this is that during this period there was a somewhat lower increase in cost of living and lower liquidity losses. Hence, interest rates on long-term bonds in the Netherlands were less than in the period before because of better liquidity and lesser demand for short term loans.

The period of 1900-1950 is very similar to the period from 1800-1850 where slightly stronger growth in the cost of living was accompanied by a rise in interest rates in the short and long term. In contrast to the period 1800-1850, the liquidity in the period 1850-1900 was better than the time before. Therefore, the demand for short-term loans was slightly lower than in the period before. Under conditions of better liquidity and lower demand for short-term loans, rising interest rates in the short and in the long run were lower than in the period 1850-1900.

The period from 1950-2012 is an entirely different story since Gibson curve disappears after 2008. Increase in this period was followed by the decline of purchasing power of monetary unit but now in high liquidity inherited from the previous period. Consequently, in terms of liquidity on the waves of credit expansion in the Netherlands, according to our model, there was expected the lower demand for short-term loans. However, under conditions of high credit expansion, inflationary expectations cause an increase in entrepreneurs' ambitions. Entrepreneurs, led by inflationary expectations and easy access to production credits with low-interest rates, push the demand for short term loans upwards.

In conditions of increasing demand for loans, banks raise interest rates. Banks' credit expansions under rising interest rates increase the gap between the market (actual) interest rate and the natural interest rate with market interest rates driven up by positive inflationary expectations. In such circumstances, prices and profits are rising, businesses operate under high turnover ratio and inventories stocks are promptly sold. The cost of living continues to rise, pushed by growth in wages and profits. Credit expansion with interest rates below the natural causes imbalances in the economy that is starting to produce below potential GDP. In terms of unused resources (capital), companies whose profits are poorer (returns on capital lower than the natural interest rate) drops out from the market. Credit expansion and low-interest rates have created the illusion of a large number of profitable companies in the Dutch economy. However, these companies have only virtually been profitable because of the cheaper cost of capital provided by "cheap" loans. Credit expansion causing imbalance in the capital market since actual interest rates were above natural (started after World War II and culminated in the period 1970-2000) had finally come to an end. Consequently, a sharp decline in the short-term interest rates and long-term interest rates took place. Final result was a higher cost of living accompanied by lower nominal long-term interest rates on Dutch long term government bonds with Gibson curve breaking down (see Fig. 4). 


\section{Conclusions}

Gibson paradox after more than 200 years continues to puzzle academics in the field of economics. This paper offers a new approach (theory) and empirical evidence on this issue. A nonlinear dynamics in the Gibson paradox is empirically proven in this study. Long-term interest rates and prices are nonlinearly cointegrated with long range dependence (long memory) in the series. Further research on Gibson paradox should take this into account and use more advanced nonlinear models in an attempt to empirically explain the odd correlation Gibson (1923) demonstrated. Gibson phenomenon is multidimensional and cannot be explained solely by the gold standards or monetary regime switching. In fact, paper results suggest that Gibson paradox is behind the long mystery of low-interest rates observed on a global scale in recent years. Gibson paradox is a result of market mechanism and when it disappears, as it is the case in the Netherlands after 2008, it is a sign that there is something wrong with the markets and not with the phenomena itself.

In this paper, we employ the microeconomic approach and offer a liquidity chain effect as an explanation of the Gibson paradox. Liquidity chain effect model brings together macroeconomic with microeconomic approaches, categories and relations in the field of demand and consumer behavior theory, business and financial economics.

The law of demand is explained by quantity - price relation, marginal utility, income effect and substitution effect. Consumption possibilities are articulated by budget constraint and influenced by income shifts and price shifts. "When the price of the good goes up, the substitution effect and the income effect both push towards reduced consumption" (Varian 1992: 145). Since we try to explain the macroeconomic phenomena of Gibson paradox by the microeconomic approach, without focusing the particular good price, but considering the general price level instead, the substitution effect is no relevant for aggregate consumption changes. So, according to the income effect, the prices changes influence the consumers' purchasing power and consumption. Consumers' purchasing power falls as the prices rise, affecting the demand to fall. That means the quantity supplied exceeds the quantity demanded, making a surplus and raising the inventories of goods unsold to rise. That brings the firms' inventory turnover ratios to decrease resulting in liquidity fall (that's why turnover ratio is often used as liquidity measure - liquidity ratios, in addition to current, acid test and quick ratio include inventory turnover ratio, also classified as activity ratio). The usual means to overcome the liquidity shortage are to speed the collection of receivables, to defer payments and to sell noncash assets. Since overall turnover is dropping, there's less receivables to collect or payments to defer or new customers to buy noncash assets. So the businesses become no longer capable of meeting short-term obligations, they must rely upon external means of solving the shortage by short or long-term borrowing or providing the additional capital investments. Since short-term borrowings are usually the least expensive mean, the demand for short-term loans increases pressing the short-term rates to increase. If the illiquidity persists and the need to overcome it by short-term borrowings appears more frequently, long-term borrowings might seem more economical than a series of short-term loans. 
Rising the microeconomic approach onto the macroeconomic level, the price level index increase is accompanied by purchasing power decrease leading the aggregate demand for goods and services to drop, resulting in surplus of aggregate supply over aggregate demand, leaving high stocks of goods unsold, making the overall inventory turnover ratio to drop. Inventory turnover ratio is raised at the macroeconomic level as a proxy for liquidity. The lower turnover, the lower liquidity as well as net operating surplus, the higher demand for short-term loans to bridge the illiquidity that makes pressure on short-term interest rates to rise. In such a way, price level increase has brought to shortterm interest rates rise. The relation stands also for long-term interest rates for loans or bonds since short-term rates are considered as their determinants, and the correlation was also empirically proved.

Beginning with price level rise, coming to the end to interest rates rise - we drew the Gibson curve based on the actual empirical data over centuries and drove our thoughts and evidences to Gibson paradox become less considered as a paradox if approached integrally employing micro and macroeconomic theory.

The relations stated above lived Gibson paradox in the Netherlands' economic history over 150 years. For the period after 1950, the relations turned vice-versa. The fall of purchasing power didn't result in turnover and liquidity decrease, due to credit overexpansion, so excessive credits kept the turnover and liquidity high, high enough to motivate getting more loans and pressing the interest rates to rise. Since it reached the levels above the natural interest rate, the rise was followed by sharp decline resulting in nowadays situation of high price levels, i.e. costs of living and low interest rates in short and long term.

Reminding our questions set up on the beginning of the research, we consider Gibson paradox as a true economic fact based on the evidences presented in this paper, comprising data analysis for more than two centuries series and explanation offered by the model presented involving the microeconomic approach. Since the series provided relate on the Netherlands' economy, it is obvious that the Gibson paradox doesn't hold only for Britain over a long-term series. Trying to find out what complex mechanism lies behind this phenomenon, we relied on the postulates offered by business and financial economics, microeconomic theory heavily exploited also by macroeconomic theory, only raised up on the aggregate level. Employing them all together with contemporary monetary theory can undoubtedly help developing a more advanced modern interest rate theory. This research has tried to offer a small, empirically based step towards its further development.

\section{References}

Afzal, A.; Mirza, N. 2012. Interest rate spreads in an emerging economy: the case of Pakistan's commercial banking sector, Ekonomska istraživanja - Economic Research 25(4): 987-1004.

Barro, R. J.; Ursúa, J. F. 2008. Macroeconomic crisis since 1870, Working Paper No. 13940. NBER.

Barsky, R. B.; Summers, L. H. 1988. Gibson's Paradox and the gold standard, The Journal of Political Economy 96(3): 528-50. http://dx.doi.org/10.1086/261550 
Bos, F. 2008. The Dutch fiscal framework: history, current practice and the role of the Central Planning Bureau, OECD Journal of Budgeting 8(1): 7-48.

http://dx.doi.org/10.1787/budget-v8-art1-en

Bozoklu, Ş. 2013. Money, income, and causality: an examination for the Turkish economy, Ekonomska istraživanja - Economic Research 26(1):171-182

Broock, W. A.; Scheinkman, J. A.; Dechert, W. D.; LeBaron, B. 1996. A test for independence based on the correlation dimension, Econometric Reviews 15(3):197-235.

http://dx.doi.org/10.1080/07474939608800353

CBS. 2014. Historical Series - Publications. Cbs.N1. Statistics Netherlands.

Centraal Bureau, voor de Statistiek, Rijksuniversiteit Groningen. 2001. Tweehonderd Jaar Statistiek in Tijdreeksen 1800-1999.

Choi, I.; Saikkonen, P. 2010. Tests for nonlinear cointegration, Econometric Theory 26: 682-709. http://dx.doi.org/10.1017/S0266466609990065

Clayton, G.; Gilbert, J. C.; Sedgwick, R. 1971. Monetary theory and monetary policy in the 1970s, in Proceedings of the 1970 Sheffield Money Seminar, Semptember 13, London, Oxford University Press.

Cogley, T.; Sargent, T. J.; Surico, P. 2011. The return of the Gibson paradox. Mimeo: New York University.

Corbae, D.; Ouliaris, S. 1989. A random walk through the Gibson paradox, Journal of Applied Econometrics 4: 295-303. http://dx.doi.org/10.1002/jae.3950040307

Dickey, D. A.; Fuller, W. A. 1979. Distribution of the estimators for autoregressive time series with a unit root, Journal of the American Statistical Association 74: 427-31.

Diks, C.; Panchenko, V. 2006. A new statistic and practical guidelines for nonparametric granger causality testing, Journal of Economic Dynamics and Control 30: 1647-69.

http://dx.doi.org/10.1016/j.jedc.2005.08.008

Elliott, G.; Rothenberg, T. J.; Stock, J.H. 1996. Efficient tests for an autoregressive unit root, Econometrica: Journal of the Econometric Society 813-36. http://dx.doi.org/10.2307/2171846

Fase, M. 1972. Bond yields and expected inflation: a quantitative analysis of the Dutch experience. De Nederlandsche Bank.

Fields, T. W. 1984. A re-examination of the Gibson paradox. Garland Pub.

Fisher, I. 1930. The Theory of interest, vol. 43. New York: The Macmillan Company.

Fisher, I. 1997. The theory of interest. Pickering \& Chatto Publishers.

Gibson, A. H. 1923. The future course of high class investment values, Banker's Magazine (London) 115:15-34.

Gootzeit, M. J. 1991. Wicksell's version of Gibson's paradox, De Economist 139: 62-72.

http://dx.doi.org/10.1007/BF01460432

Gray, J.; Johnston, K. S. 1977. Accounting and management action. New York: McGraw-Hill.

Gregory, A. W.; Hansen, B. E. 1996. Residual-based tests for cointegration in models with regime shifts, Journal of Econometrics 70: 99-126. http://dx.doi.org/10.1016/0304-4076(69)41685-7

Gregory, A. W.; Hansen, B. E. 1996. Practitioners corner: tests for cointegration in models with regime and trend shifts, Oxford Bulletin of Economics and Statistics 58: 555-60. http://dx.doi. org/10.1111/j.1468-0084.1996.mp58003008.x

Hart, M.; Jonker, J.; van Zanden, J. L. 2010. A financial history of the Netherlands. Cambridge: Cambridge University Press. 252 p.

International Institute of Social History. 2013. International Institute of Social History. Royal Netherlands Academy of Arts and Sciences. Available from Internet: http://www.iisg.nl/archives/en/ 
Ivanovski, Z.; Stojanovski, T. D.; Ivanovska, N. 2013. Interest rate risk of bond prices on Macedonian stock exchange - empirical test of the duration, modified duration and convexity and bonds valuation, Ekonomska istrazivanja-Economic Research 26(3): 47-62.

Jacobs, J.; Smits, J. P. 2001. Business cycles in the Netherlands, 1815-1913. Groningen: University of Groningen.

Keynes, J. M. 1976. A Treatise on money, vol. 2. AMS Press.

Johansen, S. 1988. Statistical analysis of cointegration vectors, Journal of Economic Dynamics and Control 12: 231-254. http://dx.doi.org/10.1016/0165-1889(88)90041-3

Johansen, S.; Juselius, K. 1990. Maximum likelihood estimation and inference on cointegration - with applications to the demand for money, Oxford Bulletin of Economics and Statistics 52: 169-210. http://dx.doi.org/10.1111/j.1468-0084.1990.mp52002003.x

Keynes, J. M.; Greene, W. 1930. Treatise on money: pure theory of money, vol. I. Martino Publishing.

Kočenda, E. 2001. An alternative to the BDS test: integration across the correlation integral, Econometric Reviews 20: 337-351. http://dx.doi.org/10.1081/ETC-100104938

Kwiatkowski, D.; Phillips, P. C. B.; Schmidt, P.; Shin, Y. 1992. Testing the null hypothesis of stationarity against the alternative of a unit root* 1 : how sure are we that economic time series have a unit root?, Journal of Econometrics 54: 159-78.

http://dx.doi.org/10.1016/0304-4076(92)90104-Y

Lo, A. W. 1991. Long-term memory in stock market prices, Econometrica 59: 1279-1313.

http://dx.doi.org/10.2307/2938368

Maddala, G. S.; In-Moo Kim. 1998. Unit roots, cointegration, and structural change. Cambridge: Cambridge University Press.

Minović, J. Z. 2012. Liquidity of the Croatian stock market: an empirical analysis, Ekonomska istraživanja - Economic Research 25(3): 776-802.

Muscatelli, V. A.; Spinelli, F. 1996. Gibson's paradox and policy regimes: a comparison of the experience in the US, UK and Italy, Scottish Journal of Political Economy 43: 468-92.

http://dx.doi.org/10.1111/j.1467-9485.1996.tb00858.x

Netherland, Statistics. 111 Jaar Statistiek in Tijdreeksen, 1899-2010. Cbs.Nl. Roterdam: Central Bureau of Statistics, the Netherlands.

Netherland Statistics. National Accounts of the Netherlands 2011. Cbs.Nl. The Hague/Heerlen: Statistics Netherlands.

Nederlandsche Bank. 2013. Statistics. Dnb. N1. De Nederlandsche Bank. Available from Internet: http://www.dnb.nl/home/index.jsp

Ng, S.; Perron, P. 2001. Lag length selection and the construction of unit root tests with good size and power, Econometrica 69: 1519-54. http://dx.doi.org/10.1111/1468-0262.00256

Officer, L. H.; Williamson, S. H. 2013. Measuring Worth [online], [cited 19 June 2014]. Available from Internet: measuringworth.com.

Phillips, P. C.; Perron, P. 1988. Testing for a unit root in time series regression, Biometrika 75: 335-346. http://dx.doi.org/10.1093/biomet/75.2.335

Ram, R. 1987. A broader multicountry perspective on the Gibson paradox and Fisher's hypothesis, De Economist 135: 219-230. http://dx.doi.org/10.1007/BF01718263

Reinhart, C. M.; Rogoff, S. K. 2009. This time is different: eight centuries of financial folly. Princeton: Princeton University Press. 512 p.

Sargent, T. J. 1973. Interest rates and prices in the long run: a study of the Gibson paradox, Journal of Money, Credit and Banking 5: 385-449. http://dx.doi.org/10.2307/1991332 
Shiller, R. J.; Siegel, J. J. 1977. The Gibson paradox and historical movements in real interest rates, The Journal of Political Economy 891-907. http://dx.doi.org/10.1086/260614

Smits, J.-P.; Edwin, H.; van Zanden, J. L. 2000. Dutch GNP and its components, 1800-1913. Groningen: Groningen Growth and Development Centre.

Sylla, R.; Homer, S. 2013. A history of interest rates. Hoboken, NJ: Wiley.

van Bochove, C. A.; Huitker, T. A. 1987. Main national accounting series, 1900-1986. Cbs.Nl. Central Bureau of Statistics, Hague, The Netherlands.

van den End, J. W. 2011. Statistical evidence on the mean reversion of interest rates, DNB Working Papers 284. Netherlands Central Bank, Research Department, Hague.

Varian, H. R. 1992. Microeconomic analysis. $3^{\text {rd }}$ ed. New York: W.W. Norton \& Company, Inc. van Zanden, J. L.; van Riel, A. 2000. Nederland 1780-1914. Staat: Instituties en Economische Ontwikkeling.

van Zanden, J. L.; Lindblad, J. T. 1989. De Buitenlandse Handel Van Nederland, 1872-1913, Economischen Sociaal-Historisch Jaarboek 52: 231-269.

von Mises, L. 2011. On the manipulation of money and credit. P. L. Greaves (Ed.). Indianapolis. Liberty Fund.

Wicksell, K. 1936. Geldzins and Guterpreise [Interest and prices]. B. Ohlin, F. Richard (Eds). New York: KahnSentry Press.

Marinko ŠKARE. Professor of Economics, Editor in Chief of the Economic Research Journal, Member of Editorial Board of several international journals, Faculty of Economics and Tourism "Dr. Mijo Mirković" in Pula, Juraj Dobrila University of Pula. He served as Assistant Dean for Education, Faculty of Economics and Tourism, Pula; Assistant Dean for International Cooperation, Faculty of Economics and Tourism, Pula, Main and Team Researcher on several scientific projects; Former Dean of the Faculty of Economics \& Tourism, Pula and Former Vice President for International Cooperation, Juraj Dobrila University of Pula. He is a member of the American Economic Association, Royal Economic Society, Economic History Association, Economic History Society, and Association for Comparative Economic Studies. He has published several books and a large number of scientific papers on the subject of economic growth, welfare economics and poverty, human capital, economics in transition, economic philosophy and monetary economics.

Research interests: Economic growth, Welfare economics, Poverty, Macroeconomics, Innovations, Economic philosophy, History of economic thoughts, Macroeconometrics.

Lorena MOŠNJA-ŠKARE. Professor of Accounting, Faculty of Economics and Tourism "Dr. Mijo Mirković" of Juraj Dobrila University of Pula, member of Editorial Board of four international journals, member of AAA, vice-rector for Business Affairs and Finance at Juraj Dobrila University of Pula, former president of Juraj Dobrila University Council, mentor of five PhD-s, she was the main researcher on three scientific projects, has co-published/edited three books and about forty scientific papers in the field of financial reporting harmonisation, international accounting/financial reporting standards, current value accounting, social accounting, management accounting, strategic accounting, internal auditing, etc. She has developed strong international scientific collaboration with researchers from University of Bologna, Roma 3, Urbino, Boston, Tartu, Ljubljana, Rollins College, etc.

Research interests: Accounting, International standards, National accounting, Auditing, Strategic accounting, Social accounting. 